\title{
B.E.A. \\ MONEY SUPPLY AND ECONOMIC GROWTH; THE CASE OF TURKEY
}

\author{
PARA ARZI VE EKONOMIK BÜYÜME: \\ TÜRKIYYE ÖRNEĞİ
}

\author{
Assoc. Prof. Mehmet Adak (Ph.D. in Economics) \\ Yalova University, Economics Department, \\ mehmet.adak@yalova.edu.tr
}

\begin{abstract}
T his paper will analyze the money supply effects on economic growth. The analysis covers the years between 1987 and 2007. The Analysis is set on a quarterly dataset basis. The ordinary least square method is employed after analyzing each variable time series. Each variable's time series is analyzed separately wherein the statistical inter-relations are revealed. The linear model is used between two variables with Ordinary Least Square Method. The econometric analysis outputs show that there is causality between money supply and economic growth in Turkey. The positive effect of money supply growth in the first quarter can be seen in the first (same) quarter and fourth quarter of economic growth. In the second and third quarters, the influence of money growth on economic growth rates is negative.
\end{abstract}

Keywords: Central Bank, Economic Growth, Money Supply, Time Series Analysis, Heteroskedasticity, Autocorrelation

JEL Classification Codes: E10, E51, E58

\section{Özet}

Bu çalışmada ekonomik büyüme üzerine etki eden para arzı analiz edilmeye çalışılmıştır. Analiz 1987 -2007 yılları arasını kapsayan üçer aylık veri kümesi üzerinden yapılmıştır. Her bir değişkene ait serisinin zaman analizinden sonra en düşük kareler yöntemi aracılığ ile iki değişken (para arzı - ekonomik büyüme) arasındaki ilişki sınanmaya çalışılmıştır. ekonometrik analiz sonucunda Türkiye'de para arzı ile ekonomik büyüme arasında bir nedensellik ilişkisi tespit edilmiştir. Para arzının yaşanması sonucu para arzının yaşandığı aynı dönemde (1. çeyrek) ve para arzının yaşanmasını takip eden 4. dönemde (4. çeyrek) ekonomik büyümede artış yaşandığı. Para arzını takip eden 2. ve 3. dönemlerde (2. ve 3 . çeyrekler) para arzının ekonomik büyüme üzerine negatif etki bıraktığı gözlemlenmiştir.

Anahtar Kelimeler: Merkez Bankası, Ekonomik Büyüme, Para Arzı, Zaman Serileri Analizi, Değișen Varyans, Otokorelasyon

JEL Sınıflama Kodları: E10, E51, E58 


\section{Introduction}

The Turkish economy started to integrate into the global economy after 1980. The national production began to increase rapidly over the next 30 years. However, the most significant increase in production was only seen after the year 2001. There were four major shocks experienced between 1994 and 2001. These crises were caused by domestic, political and economic problems. The last shock was because of global economic problems. Politic stability was the main factor behind the production increase after 2001 . The national domestic production of Turkey went up from 68.8 billion US Dollars in 1980 to 730.2 billion US Dollars in the year 2008 just before the global crisis.

The Central Banks of The Republic of Turkey first began to activate in October 1931. The main goal of the bank was to support national development. The bank's policy tools were; to issue money, to announce re-discount rates, to regulate the financial market and money circulation in the market, to control treasury activities and to protect the value of the Turkish national currency. The inflation rate stayed at a low level in this period.

In the 1940's The Central Bank began to be recognized as a financial institution of public budget deficit. The public debts were mainly financed by the Central bank issuing notes which in turn, caused inflation in the Turkish economy. As a result, new regulations were then issued in 1950 concerning the Central Bank's short term advances to the treasury. Despite these new regulations, the central bank was lax with the new rules and continued some of its old policies in the 60s. By this time, the inflation rates could be clearly seen across the economy. Foreign Exchange transaction authorization was also given to the central bank in this period.

The new central bank act was accepted in $14^{\text {th }}$ January 1970 . The central bank's influences on direct and indirect monetary policy instruments were increased by the new act. The central bank was authorized to regulate the money supply in the market by open market operations.

Free market policies were allowed into the Turkish economy in the 1980s. The Central bank's monetary and exchange rate policies became more crucial in these years. The Central bank's main goal after 1983 was to have price stability in the Turkish economy. The authority of managing foreign exchange reserves and gold reserves by the central bank was agreed upon as well. The Turkish currency became convertible in 1989. The Turkish Central Bank announced the first monetary program in 1990.

The Central Bank's public financing was restricted after the financial crisis of 1994. However, the Turkish Central Bank was given the choice to select any monetary instrument after 2001. Inflation targeting policies began in 2002. Six digit zeros were removed from the Turkish Currency. Short term interest rates were also adopted as a new monetary policy instrument. 


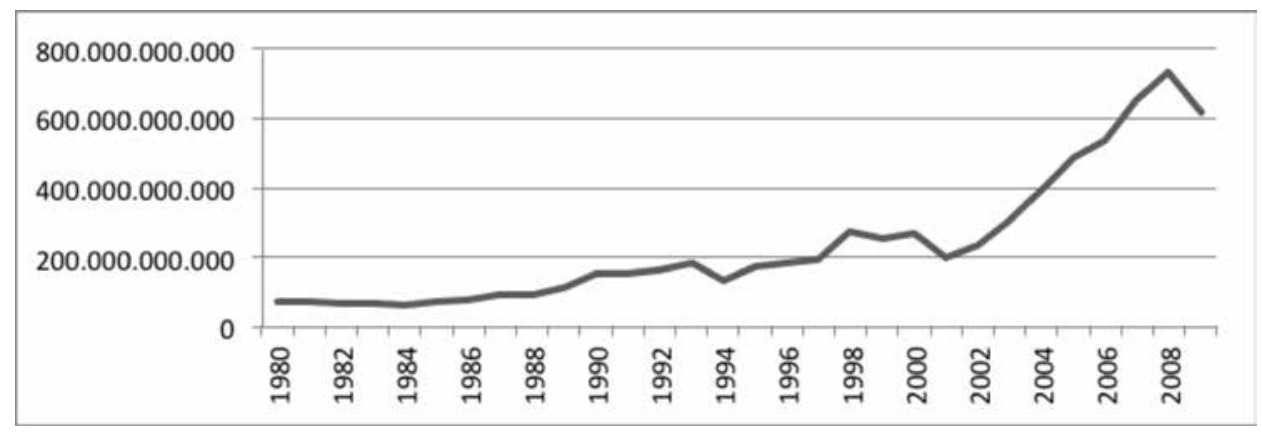

Figure 1. GDP (Current US Dollar) (Source: World Bank)

The fraction of money and quasi money supply (M2) to GDP increased over the last 3 decades. The ratio (M2/GDP) was $14.1 \%$ in 1980 and reached $43.7 \%$ in 2008.

The Turkish Central Bank law was modernized in the 90s and 2000s. The central bank was assumed to be a source of budget for the government but by changing the financial laws it became an independent institution which attempts to keep price stability in the market.

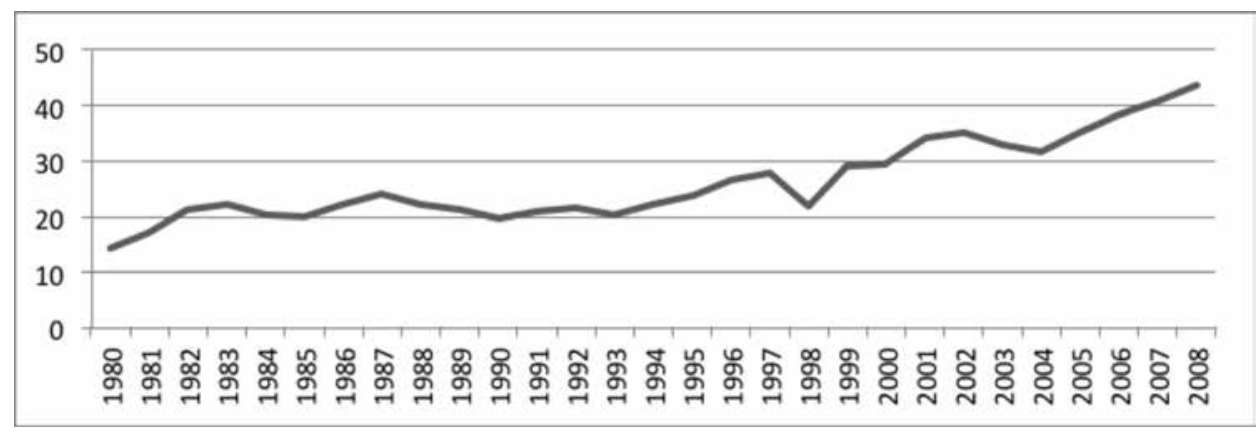

Figure 2. Money and Quasi Money (M2) as \% of GDP (Source: World Bank)

\section{Economic Literature (a brief summary)}

Minsky (1957) and Kaldor worked on causality relations of money and income relations. They found that there is causality from money to income. Kaldor (1958) claims that any changes in money supply does not influence money demand and that there can be a relation between money supply and interest rate. Friedman and Schwartz (1963) showed that the changes in real output usually come after fluctuations in money supply. Tobin built a closed economic model. There are no endogenous variables like money in this model. The money stock is only issued by the central government and it remains exogenous. Econo- 
mic individuals usually manage their portfolios. The real capital's values in individuals' portfolios play a great role in the economy. Tobin argued that any increases in inflation rates increase the value of capital stock in an economy (Tobin, 1965). Clower (1967) built a model where money is the exchange instrument in the economy. It also plays a transaction role in the economy. The Keynesian economics describe the effect of money in the economy using the IS-LM model. The financial market and goods market complete each other. The post-Keynesian economics focuses on Phillips Curve which became a major policy tool for controlling unemployment and inflation rates. This relation was not seen as sustainable for long run analysis. Money supply is accepted as pro-cyclical in economies. The output cycles follow the Money supply cycles. FED former president Paul Volcker argued that tightly controlled Money Supply policies can cause recessions in the market. Thirlwall (1987) argues that exogenous money supply is a cause for income. McCallum (1988) tried to show that money growth is influenced by economic growth rate. He also says that central banks reduce money supply when the expected inflation rate is high. The relation between money supply and economic growth was analyzed in the VAR (Vector Auto Regression) models. Sims (1992) shows the interrelation of money and output in six developed countries' economies (France, Germany, UK, Japan, and U.S.). Moore (1991) proved the causality relation of money to income. Taylor (1993) worked on US economic growth. He worked on an equation which is named after him. He tried to prove that FED target interest rates and expected inflation rates are the major variables on economic growth function. Taylor (2001) included the exchange rate in his models. Rudebusch and Suensson (1999) ignored the Money Supply variable in their economic model. Nelson (2002) argues that base money is interrelated with output in UK and USA's economies. The long term nominal rate in money demand function increases the effect of nominal money stock changes on real aggregate demand. Leeper and Roush (2003) found that Money supply can change the rate of output and inflation. Hafer, Haslag and Jones (2007) found that there is a significant relationship between Money supply and output. Fan, Yu and Zhang (2011) found that Money supply has influence on inflation rates and real output.

\section{Data Set}

The economic series which are used in this analysis come from different sources. The Gross National Product (GNP) series is from the Turkish Statistics Institute's database. This series was prepared according to 1987 fixed prices for every quarter. The GNP growth rate is calculated by working out the difference of the $t$ period GNP value from $t-1$ period GNP value and then dividing the difference to $t-1$ GNP value.

The money supply statistics were taken from Central Bank's data base. The definition of Money supply in this analysis is the sum of currency outside the banks, demand deposits and monetary authorities (deposit money banks, participation banks and investment - development banks). The Money supply definition is not covering any quasi Money items. The original series is being monitored and published monthly. The monthly series has been converted to a quarterly series for the analysis. The rate of Money supply for every quarter has been calculated by differentiating the $t$ period value from $t-1$ period value and dividing the difference to $t-1$ period value. The real money supply rate is calculated by subtracting the inflation rate from money supply growth rate. 
Inflation index has also been sourced from central bank's data base. The series was recorded by the Istanbul Chamber of Commerce. The base year of the index is 1968. The index is published monthly. The monthly inflation series has also been converted to a quarterly form.

Table 1. General Characteristics of Series

\begin{tabular}{|l|c|c|}
\hline & GNP & MONEY \\
\hline Mean & 0.050515 & 0.025410 \\
\hline Median & 0.075115 & 0.049444 \\
\hline Maximum & 0.592729 & 0.343358 \\
\hline Minimum & -0.276579 & -0.445394 \\
\hline Std. Dev. & 0.275645 & 0.142421 \\
\hline Skewness & 0.346941 & -0.602093 \\
\hline Kurtosis & 1.681368 & 3.911372 \\
\hline & & \\
\hline Jarque-Bera & 7.585898 & 7.792272 \\
\hline Probability & 0.022529 & 0.020320 \\
\hline & & \\
\hline Sum & 4.142190 & 2.083647 \\
\hline Sum Sq. Dev. & 6.154411 & 1.642978 \\
\hline & & \\
\hline Observations & 82 & 82 \\
\hline
\end{tabular}

General characteristics of two series are given in Table 1. GNP and Money Supply have averagely increased $5 \%$ and $2.5 \%$ quarterly. GNP increased a maximum $60 \%$ once. Money Supply increased a maximum of $34 \%$ once. The minimum development in GNP was $-27 \%$. The minimum development reached $-44 \%$ in Money Supply.

The time series Jarque-Bera probability ratios could not exceed the $60 \%$ level. Therefore the series are not assumed to be in normal distribution form. Both variables' time series can be seen in Figure 3 and Figure 4. The Figure 4 is in Seasonal Form. 


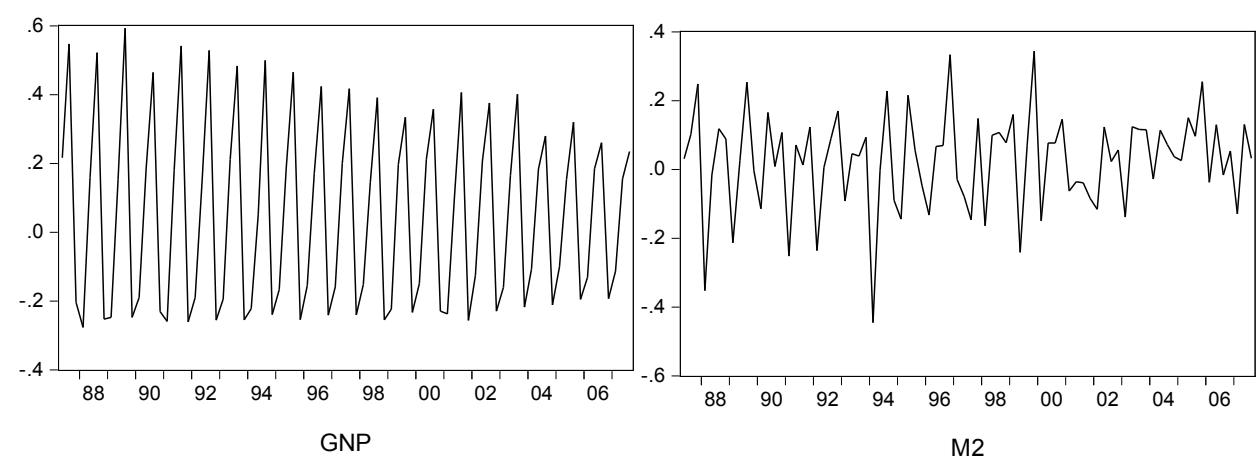

Figure 3. Time Series of Both Variables
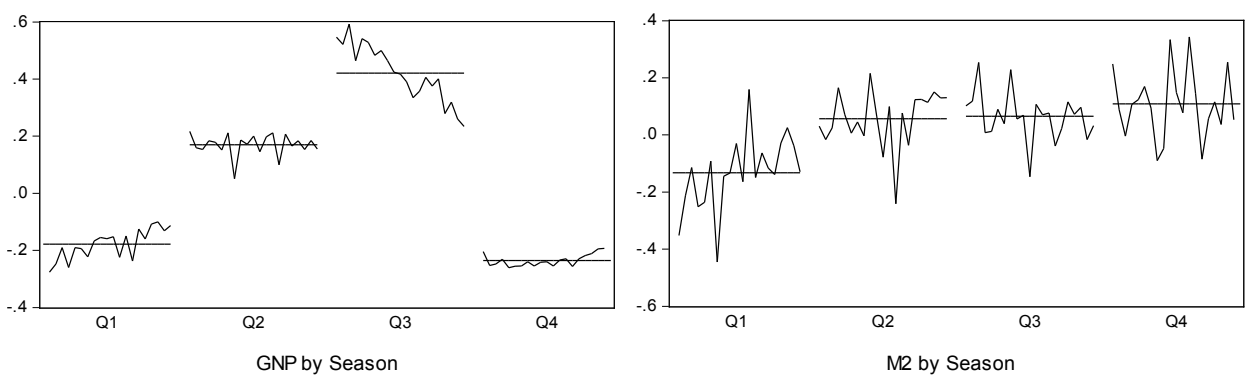

- Means by Season

Figure 4. Time Series of Both Variables in Seasonal Form

\section{Analysis}

\subsection{Stationarity Test}

Phillips-Perron unit root test has been employed for testing GNP growth rate and Money Supply growth rate series' stationarity. Intercept terms and linear trends' co-efficients are included in the Phillips-Peron unit root test regression models. The probability values are the Mackinnon (1996) one sided p-values. GNP growth rate and Money Supply growth rate series' unit root test results are shown below; 
Table 2. Phillips-Perron Statinarity Test for Money Supply Growth Rate Series

\begin{tabular}{|l|c|c|}
\hline Null Hypothesis: $\left(\frac{\Delta \text { Money }}{\text { Money }}\right)$ has a unit root \\
\hline Exogenous: Constant, Linear Trend \\
\hline Bandwidth: 33 (Newey-West using Bartlett kernel) \\
\hline \multicolumn{3}{|c|}{ Test critical values } \\
\cline { 2 - 3 } Phillips-Perron test statistic & -19.42727 & 0.0000 \\
\hline & & -4.075340 \\
\hline 1\% level & -3.466248 \\
\hline $5 \%$ level & -3.159780 \\
\hline $10 \%$ level & \\
\hline
\end{tabular}

$\mathrm{H}_{0}$ hypothesis is rejected in both tests with significant t-statistics and probability ratios. This statically means that both series are stationary in level I(0).

Table 3. Phillips-Perron Statinarity Test for GNP Growth Rate Series

\begin{tabular}{|c|c|c|}
\hline \multicolumn{3}{|c|}{ Null Hypothesis: $\left(\frac{\triangle G N P}{G N P}\right)$ has a unit root } \\
\hline \multicolumn{3}{|c|}{ Exogenous: Constant, Linear Trend } \\
\hline \multicolumn{3}{|c|}{ Bandwidth: 12 (Newey-West using Bartlett kernel) } \\
\hline \multirow{2}{*}{ Phillips-Perron test statistic } & Adj. t-Statistics & Probability \\
\hline & -17.84820 & 0.0000 \\
\hline \multicolumn{3}{|c|}{ Test critical values } \\
\hline $1 \%$ level & \multicolumn{2}{|c|}{-4.075340} \\
\hline $5 \%$ level & \multicolumn{2}{|c|}{-3.466248} \\
\hline $10 \%$ level & \multicolumn{2}{|c|}{-3.159780} \\
\hline
\end{tabular}

\subsection{Granger Causality Test}

The granger causality test is used to find the direction of causality between the variables. The equations below are designed as one dependent variable which is dependent on the past values of itself as well as that of other independent variables' past values. The lag length was selected 4 in the model.

$$
\begin{aligned}
& \left(\frac{\Delta G N P}{G N P}\right)_{t}=\sum_{i=1}^{n} \gamma_{i}\left(\frac{\Delta G N P}{G N P}\right)_{t-1}+\sum_{j=1}^{n} \beta \delta_{j}\left(\frac{\Delta \text { Money }}{\text { Money }}\right)_{t-j}+u_{2 t} \\
& \left(\frac{\Delta \text { Money }}{\text { Money }}\right)_{t}=\sum_{i=1}^{n} \alpha_{i}\left(\frac{\Delta \text { Money }}{\text { Money }}\right)_{t-1}+\sum_{j=1}^{n} \beta_{j}\left(\frac{\Delta G N P}{G N P}\right)_{t-j}+u_{1 t}
\end{aligned}
$$


Table 4. Granger Causility Test Results

\begin{tabular}{|c|c|c|}
\hline \multicolumn{3}{|l|}{ Pairwise Granger Causality Tests } \\
\hline \multicolumn{3}{|l|}{ Sample: 1987Q2 2007Q3 } \\
\hline \multicolumn{3}{|l|}{ Lags: 4} \\
\hline \multicolumn{3}{|l|}{ Observations: 78} \\
\hline Null Hypothesis & F-Statistics & Probability \\
\hline$\left(\frac{\Delta \text { Money }}{\text { Money }}\right)$ does not Granger Cause $\left(\frac{\Delta G N P}{G N P}\right)$ & 2.30293 & 0.0671 \\
\hline$\left(\frac{\Delta G N P}{G N P}\right)$ does not Granger Cause $\left(\frac{\Delta \text { Money }}{\text { Money }}\right)$ & 5.68520 & 0.0005 \\
\hline
\end{tabular}

There is a direction of causality from Money supply growth to GNP growth. The estimated $\mathrm{F}$ Value is significant at a $10 \%$ level. There is also a reverse causation from GNP growth to Money supply growth. The F values were found significant. The critical F value is 2.018 for 4 and 78 degrees of freedom.

\subsection{Covariance and Correlation Analyses}

A positive relation can be recognized from covariance and correlation matrixes between the two variables. All calculated values are found positive in the matrixes. The relation is not very strong. All calculated values were found less than 0.50 between two variables.

Table 5. Covariance Matrix

\begin{tabular}{|c|c|c|}
\hline & $\left(\frac{\Delta G N P}{G N P}\right)$ & $\left(\frac{\Delta \text { Money }}{\text { Money }}\right)$ \\
\hline$\left(\frac{\Delta G N P}{\text { GNP }}\right)$ & 0.07505 & 0.00952 \\
\hline$\left(\frac{\Delta \text { Money }}{\text { Money }}\right)$ & 0.00952 & 0.02003 \\
\hline
\end{tabular}

Table 6. Correlation Matrix

\begin{tabular}{|c|c|c|}
\hline & $\left(\frac{\Delta G N P}{G N P}\right)$ & $\left(\frac{\Delta \text { Money }}{\text { Money }}\right)$ \\
\hline$\left(\frac{\Delta G N P}{\text { GNP }}\right)$ & 1 & 0.24551 \\
\hline$\left(\frac{\Delta \text { Money }}{\text { Money }}\right)$ & 0.24551 & 1 \\
\hline
\end{tabular}




\subsection{Ordinary Least Square Method}

There is a linear model design for the OLS model as shown below;

$$
\left(\frac{\Delta G N P}{G N P}\right)_{t}=\beta_{0}+\beta_{1}\left(\frac{\Delta \text { Money }}{\text { Money }}\right)_{t}+e
$$

The dependent variable $\left(\frac{\triangle G N P}{G N P}\right)_{t}$ is the GNP growth rate for $t$ period. $\beta_{0}$ is the intercept of the model. $\left(\frac{\Delta \text { Money }}{\text { Money }}\right)_{t}$ is the money supply growth rate for the period $t . \beta$ is the regression parameter. The linear model has been designed in a dynamic system and autoregression (AR) has been used for the model. The dynamic system runs with 3 lags.

The regression output with 3 lags is given below;

$\left(\frac{\Delta G N P}{G N P}\right)_{t}=\beta_{0}+\beta_{1}\left(\frac{\Delta \text { Money }}{\text { Money }}\right)_{t}+\beta_{2}\left(\frac{\Delta \text { Money }}{\text { Money }}\right)_{t-1}+\beta_{3}\left(\frac{\Delta \text { Money }}{\text { Money }}\right)_{t-2}+\beta_{4}\left(\frac{\Delta \text { Money }}{\text { Money }}\right)_{t-3}+e$

\section{Table 7. The Regression Analysis Results}

\begin{tabular}{|c|c|c|c|c|}
\hline \multicolumn{5}{|c|}{ Dependent Variable: $\left(\frac{\triangle G N P}{G N P}\right)_{t}$} \\
\hline \multicolumn{5}{|c|}{ Method: Least Squares } \\
\hline \multicolumn{5}{|c|}{ Sample (adjusted): 1988Q1 2007Q3 } \\
\hline \multicolumn{5}{|c|}{ Included observations: 79 after adjustments } \\
\hline Variable & Coefficient & Std. Error & t-statistic & Prob. \\
\hline constant & 0.050771 & 0.026279 & 1.932021 & 0.0572 \\
\hline$\left(\frac{\Delta \text { Money }}{\text { Money }}\right)_{t}$ & 0.257917 & 0.180554 & 1.428477 & 0.1574 \\
\hline$\left(\frac{\Delta \text { Money }}{\text { Money }}\right)_{t-1}$ & -0.398174 & 0.183428 & -2.170737 & 0.0332 \\
\hline$\left(\frac{\Delta \text { Money }}{\text { Money }}\right)_{t-2}$ & -0.783716 & 0.182918 & -4.284514 & 0.0001 \\
\hline$\left(\frac{\Delta \text { Money }}{\text { Money }}\right)_{t-3}$ & 0.672344 & 0.177900 & 3.779346 & 0.0003 \\
\hline R-squared & 0.451510 & \multicolumn{2}{|c|}{ Mean dependent var } & 0.045356 \\
\hline Adjusted R-squared & 0.421862 & \multicolumn{2}{|c|}{ S.D. dependent var } & 0.273003 \\
\hline S.E. of regression & 0.207579 & \multicolumn{2}{|c|}{ Akaike info criterion } & -0.245413 \\
\hline Sum squared resid & 3.188580 & \multicolumn{2}{|c|}{ Schwarz criterion } & -0.095448 \\
\hline Log likelihood & 14.69381 & \multicolumn{2}{|c|}{ Hannan-Quinn criter. } & -0.185332 \\
\hline F-statistic & 15.22895 & \multicolumn{2}{|c|}{ Durbin-Watson stat } & 2.251412 \\
\hline Prob(F-statistic) & 0.000000 & & & \\
\hline
\end{tabular}


All coefficients' $t$-statistics values exceeded the critical boundaries and remained in confidence intervals. The sign of each parameter gives information about the influences of money supply rate of each lag on economic growth rate. Money supply growth rate in period $t$ has positive effects on economic growth rate in $t$ period. The money supply growth rate in period $t-1$ and $t-2$ has negative effects on economic growth rate in period $t$. The money supply growth rate in period $t-3$ has a positive influence on GNP growth rate in $t$ period. The above model can explain $45 \%$ of economic growth rates. The adjusted R-square value was found at 42 percent. F-statistics of the regression analysis exceeded the critical value and its probability ratio was found as zero. The Durbin -Watson statistics was found 2.25 which is quite close to 2 . It strongly suggests that there is no auto-correlation in the model.

\subsection{Autocorrelation Test}

The Durbin-Watson statistics was found at 2.25 and it is close to the critical value 2 . The Breusch-Godfrey serial correlation LM test has been employed for autocorrelation testing. The serial correlation (LM) Test depends on the residual AR(1) model and AR(1)'s coefficient significancy. The test regression model is designed as follows;

The LM test results are given below;

$e=\beta_{0}+\beta_{1}\left(\frac{\Delta \text { Money }}{\text { Money }}\right)_{t}+\beta_{2}\left(\frac{\Delta \text { Money }}{\text { Money }}\right)_{t-1}+\beta_{3}\left(\frac{\Delta \text { Money }}{\text { Money }}\right)_{t-2}+\beta_{4}\left(\frac{\Delta \text { Money }}{\text { Money }}\right)_{t-3}+\beta_{5} e_{t-1}$

Table 8. Breusch-Godfrey Serial Correlation LM Test

\begin{tabular}{|c|c|c|c|c|}
\hline F-statistic & 1.398147 & \multicolumn{2}{|c|}{ Probability F(1,73) } & 0.2409 \\
\hline $\begin{array}{l}\text { Number of Observation X } \\
\text { (R-squared) }\end{array}$ & 1.484629 & \multicolumn{2}{|c|}{$\begin{array}{l}\text { Probability Chi- } \\
\text { Square(1) }\end{array}$} & 0.2231 \\
\hline \multicolumn{5}{|l|}{ Dependent Variable: $e$} \\
\hline \multicolumn{5}{|l|}{ Method: Least Squares } \\
\hline \multicolumn{5}{|l|}{ Sample: 1988Q1 2007Q3 } \\
\hline \multicolumn{5}{|l|}{ Included observations: 79} \\
\hline Variable & Coefficient & Std. Error & t-Statistic & Prob. \\
\hline constant & -0.003665 & 0.026391 & -0.138880 & 0.8899 \\
\hline$\left(\frac{\Delta \text { Money }}{\text { Money }}\right)_{t}$ & 0.081090 & 0.192687 & 0.420837 & 0.6751 \\
\hline$\left(\frac{\Delta \text { Money }}{\text { Money }}\right)_{t-1}$ & 0.027270 & 0.184385 & 0.147895 & 0.8828 \\
\hline$\left(\frac{\Delta \text { Money }}{\text { Money }}\right)_{t-2}$ & 0.027057 & 0.183858 & 0.147161 & 0.8834 \\
\hline$\left(\frac{\Delta \text { Money }}{\text { Money }}\right)_{t-3}$ & 0.016983 & 0.178003 & 0.095411 & 0.9242 \\
\hline $\mathbf{e}_{\mathrm{t}-1}$ & -0.146884 & 0.124222 & -1.182433 & 0.2409 \\
\hline R-squared & 0.018793 & Mean d & endent var & $1.37 \mathrm{E}-17$ \\
\hline
\end{tabular}


F-statistics values are calculated by taking the square power of $e_{\mathrm{t}-1}$ terms's t-statistics value;

$$
\text { F-statistics }=(-1.182433)^{2}=1.398147
$$

The LM test statistics $\left(\chi^{2}\right)$ is calculated by multiplying the observation number with R-square value;

$$
\chi^{2}=(79) \cdot(0.018793)=1.4846
$$

There are two hypotheses for the autocorrelation test;

$$
\begin{aligned}
& \mathrm{H}_{0}: \beta_{5}=0 ; \text { There is no serial correlation } \\
& \mathrm{H}_{1}: \beta_{5} \neq 0 \text { There is serial correlation }
\end{aligned}
$$

Since the calculated Breusch-Godfrey LM test statistics of $\mathbf{1 . 4 8 4 6 2 9}$ does not exceed the critical $\chi^{2}(1)$ value $\mathbf{3 . 8 4 1 4 5}$, we cannot reject the null hypothesis of no serial correlation up to lag order 1 at the 95 percent confidence level.

\subsection{Heteroskedasticity Test}

The heteroskedasiticity test works by following the model shown below. The model is performed using the White Test. The Model depends on the relation of squared residual and the square of each independent variable series. There is no cross term included in the model.

$e_{i}^{2}=\beta_{0}+\beta_{2}\left[\left(\frac{\Delta \text { Money }}{\text { Money }}\right)_{t}\right]^{2}+\beta_{3}\left[\left(\frac{\Delta \text { Money }}{\text { Money }}\right)_{t-1}\right]^{2}+\beta_{4}\left[\left(\frac{\Delta \text { Money }}{\text { Money }}\right)_{t-2}\right]^{2}+\beta_{5}\left[\left(\frac{\Delta \text { Money }}{\text { Money }}\right)_{t-3}\right]^{2}+v_{i}$

The chi-sqaure value is calculated as;

$$
\begin{gathered}
\chi^{2}=(\text { number of observation }) \times(R-\text { squared }) \\
5.898095=\chi^{2}=(79) \times(0.074659)
\end{gathered}
$$

The calculated value is compared with critical chi-square value. The critical chi-square value is $\chi_{0.95,4}^{2}=9.48772$ at 5 percent significance level. The critical chi-square value is greater than calculated chi-square value. That's why the null hypothesis of no heteroskedasicity cannot be rejected at 5 percent significance level.

$$
\begin{aligned}
& \mathrm{H}_{0} \text { : There is no heteroskedasticity, } \mathrm{H}_{0}: \beta_{2}=\beta_{3}=\beta_{4}=\beta_{5}=0 \\
& \mathrm{H}_{1} \text { : There is heteroskedasticity, } \mathrm{H}_{1}: \beta_{2} \neq \beta_{3} \neq \beta_{4} \neq \beta_{5} \neq 0
\end{aligned}
$$

Table 9. The Heteroskedasticity Test (White Test)

\begin{tabular}{|l|l|l|c|}
\hline F-statistic & 1.492639 & Probability F(4,74) & 0.2131 \\
\hline $\begin{array}{l}\text { Number of Observation X } \\
\text { R-squared) }\end{array}$ & 5.898095 & Probability Chi-Square(4) & 0.2069 \\
\hline \multicolumn{2}{|l|}{} \\
\hline
\end{tabular}




\begin{tabular}{|c|c|c|c|c|}
\hline \multicolumn{5}{|l|}{ Dependent Variable: $e^{2}$} \\
\hline \multicolumn{5}{|l|}{ Method: Least Squares } \\
\hline \multicolumn{5}{|c|}{ Sample: 1988Q1 - 2007Q3 } \\
\hline \multicolumn{5}{|c|}{ Included observations: 79} \\
\hline Variable & Coefficient & Std. Error & t-Statistic & Prob. \\
\hline constant & 0.034961 & 0.011478 & 3.045977 & 0.0032 \\
\hline$\left[\left(\frac{\Delta \text { Money }}{\text { Money }}\right)\right]_{t}^{2}$ & 0.370333 & 0.203272 & 1.821857 & 0.0725 \\
\hline$\left[\left(\frac{\Delta \text { Money }}{\text { Money }}\right)_{t-1}\right]$ & -0.106929 & 0.202775 & -0.527329 & 0.5995 \\
\hline$\left(\frac{\Delta \text { Money }}{\text { Money }}\right)_{t-2}$ & 0.174416 & 0.202722 & 0.860371 & 0.3924 \\
\hline$\left[\left(\frac{\Delta \text { Money }}{\text { Money }}\right)_{t-3}\right.$ & -0.172657 & 0.201241 & -0.857961 & 0.3937 \\
\hline R-squared & 0.074659 & Mean d & endent var & 0.040362 \\
\hline
\end{tabular}

\subsection{Residual Analysis}

The residual series was found to be roughly normally distributed. Skewnees value was found -0.1155 which is close to zero. The Kurtosis value was found 3.10972 which is close to 3 . These values can be called econometrically significant. The probability value of Jarque-Bera statistics was found 0.89791 . The probability value exceeded the critical value 0.05 .

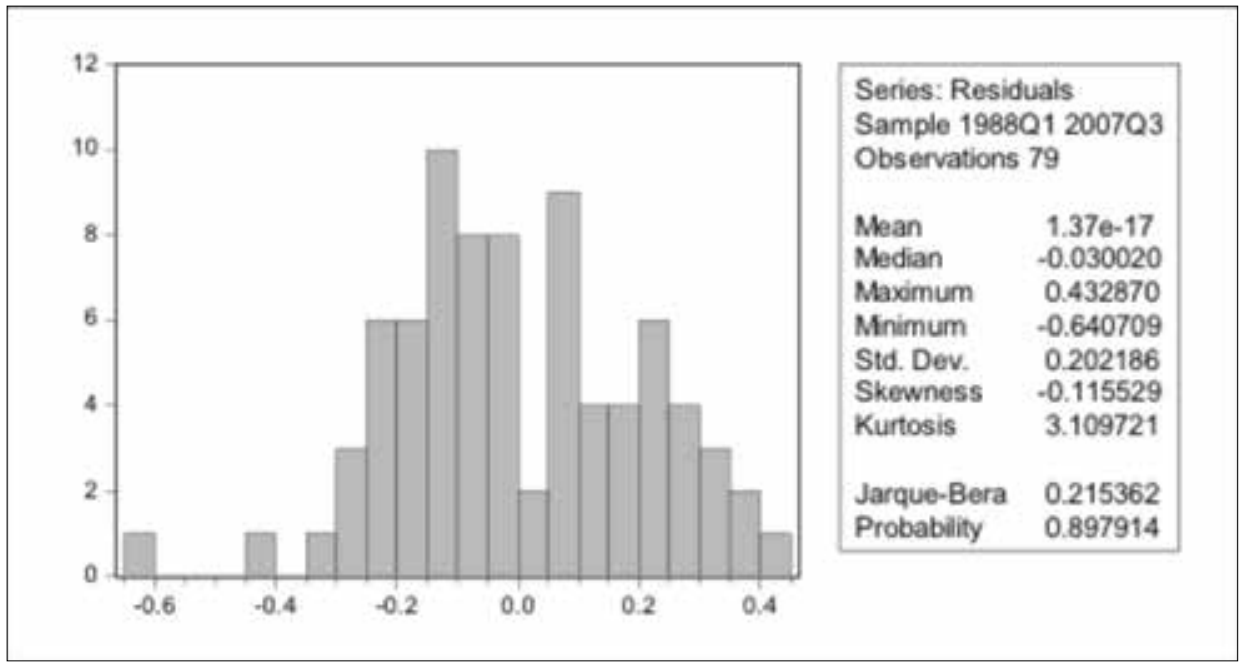

Figure 5. Residual Series's Distribution 


\section{Conclusion}

Money supply and economic growth interrelation was examined using the Least Square Method in this paper. The effect of money supply on economic growth was analyzed using the dynamic system. The influence of money supply growth in $t$ period has positive effects on economic growth in the same $(t)$ period. The same analysis was done for $t-1$ and $t-2$ periods, the effects of money supply growth in $t-1$ and $t-2$ lags had a negative influence on economic growth rate in $t$ period. Finally, the $t$ - 3 period's money supply growth rates showed positive effects on economic growth rate in $t$ period.

The money supply was accepted as a familiar financing tool for central budgets in Turkey until the year 2001. The populist governments never hesitated to use this instrument. The inflation and economic crises alternately followed each other until the year 2001. Two major currency devaluations occurred in1990 and 2001.

This analysis shows the dangers of populist governments using the Central bank as a main financial source. The money supply can give partial optimistic effects on economic growth when the central budget is in deficit (as seen in the first period). However, its negative effects are very clear in the second and third periods were too much money was issued to the economy. The monetary base enlargement became the cause of inflation which in turn ruined the price levels in markets, imports, investment plans and income distribution. The economy was only able to manage the new enlargement in the fourth period and hence follow its natural growth path.

The Turkish economy designed new strict financial laws and fiscal management acts after the year 2003. The fiscal policy makers currently work on reliable budgets and the money supply is left as a financial source for the central budget.

The Central Bank management has now become more respectable and its financial operations more effective. 


\section{References}

Clower, R. W. (1967). A Reconsideration of the micro foundations of monetary theory. Western Economic Journal, 6, 1-9.

Friedman, M., Schwartz, A.J. (1963). Money and business cycles. Review of Economics and Statistics, 45, 32-64.

Kaldor, N. (1958). Monetary policy, economic stability and growth. A memorandum submitted to the Committee of the Working of the Monetary System (Radcliffe Committee), June 23. Reprinted in Collected Economic Papers, Volume 3, Essays on Economic Policy 1 (1964) London: Duckworth

Leeper, E.M., J.E. Roush (2003). Putting 'M' back into monetary policy, Journal of Money Credit and Banking, 35, 1217-1256.

Longzhen Fan a, Yihong Yu a, Chu Zhang (2011). An empirical evaluation of China's monetary policies, Journal of Macroeconomics, 33, 358-371

McCallum, B., (1988). Robustness properties of a rule for monetary policy. Carnegie-Rochester Conference Series on Public Policy, 29, 173-204.

Minsky, H. (1957). Central banking and money market changes. Quarterly Journal of Economics, 71(2) 171-87.

Moore, B. (1991). Money supply endogeneity: 'reserve price setting' or 'reserve quantity setting?', Journal of Post Keynesian Economics, 13(3): 404-13.

Nelson, E. (2002). Direct effects of base money on aggregate demand: theory and evidence, Journal of Monetary Economics, 49 (4), 687-708.

R.W. Hafera, Joseph H. Haslagb, Garett Jonesc (2007). On money and output: Is money redundant?, Journal of Monetary Economics, 54, 945-954

Rudebusch, G.D., Lars .E.O Svensson (1999). Policy rules for inflation targeting. In:Taylor, J.B. (Ed.) Monetary Policy Rules. (pp. 203-246) University of Chicago Press, Chicago.

Rudebusch, G.D., Lars E.O. Svensson (2002). Eurosystem monetary targeting: lessons from US data, European Economic Review, 46, 417-442.

Sims, C.A. (1992). Interpreting the macroeconomic time series facts: the effects of monetary policy. European Economic Review, 36, 975-1000.

Taylor, J.B. (1993). Discretion versus policy rules in practice. Carnegie-Rochester Conference Series on Public Policy, 39, 195-214.

Taylor, J.B. (2001). The role of the exchange rate in monetary policy rules, American Economic Review, 91, 263-267.

Thirlwall, A. P. (1987). Nicholas Kaldor. The New York University Press, New York Tobin, J. (1965). Money and economic growth, Econometrica, 33, 671-684. 